\title{
CORRIGENDUM
}

\section{Epigenetic inactivation of paired box gene 5, a novel tumor suppressor gene, through direct upregulation of p53 is associated with prognosis in gastric cancer patients}

X Li, KF Cheung, X Ma, L Tian, J Zhao, MYY Go, B Shen, ASL Cheng, J Ying, Q Tao, JJY Sung, H-f Kung and J Yu

Oncogene (2012) 31, 3482; doi:10.1038/onc.2012.185

Correction to: Oncogene (2012) 31, 3419-3430; published online 21 November 2011; doi:10.1038/onc.2011.511

Since the publication of the above manuscript, the authors have identified an error; the PAX5 gene is located on chromosome $9 \mathrm{p} 13$, not $19 \mathrm{p} 13$ as stated in the article. 